University of Louisville

ThinkIR: The University of Louisville's Institutional Repository

College of Arts \& Sciences Senior Honors

Theses

College of Arts \& Sciences

$5-2016$

\title{
The Western diet's negative impact on the health of the Pacific Islands.
}

Jessica Ruikka

Follow this and additional works at: https://ir.library.louisville.edu/honors

Part of the Anthropology Commons, and the Nutrition Commons

Recommended Citation

Ruikka, Jessica, "The Western diet's negative impact on the health of the Pacific Islands." (2016). College of Arts \& Sciences Senior Honors Theses. Paper 99.

http://doi.org/10.18297/honors/99

This Senior Honors Thesis is brought to you for free and open access by the College of Arts \& Sciences at ThinkIR: The University of Louisville's Institutional Repository. It has been accepted for inclusion in College of Arts \& Sciences Senior Honors Theses by an authorized administrator of ThinkIR: The University of Louisville's Institutional Repository. This title appears here courtesy of the author, who has retained all other copyrights. For more information, please contact thinkir@louisville.edu. 
The Western Diet's Negative Impact on the

Health of the Pacific Islands

By

Jessica Ruikka

University of Louisville

Submitted to fulfill requirements for Graduation (summa or magna)

Cum laude and for Graduation with Honors from

University of Louisville 


\section{Table of Contents}

Background 3

Abstract 3

Introduction 3

Current Health

Challenges $\quad 8$

Health Care \& Health Costs $\quad 8$

Poverty, Population Increase \& Food Security $\quad 10$

$\begin{array}{ll}\text { Agriculture } & 12\end{array}$

$\begin{array}{ll}\text { Fisheries } & 14\end{array}$

$\begin{array}{ll}\text { Environment } & 15\end{array}$

$\begin{array}{ll}\text { Urban vs. Rural Living } & 16\end{array}$

$\begin{array}{ll}\text { Cultural Setbacks } & 18\end{array}$

$\begin{array}{ll}\text { Current Interventions } & 19\end{array}$

$\begin{array}{ll}\text { Food Policy } & 20\end{array}$

$\begin{array}{ll}\text { Sin Taxation } & 21\end{array}$

$\begin{array}{ll}\text { Fisheries } & 22\end{array}$

Health Promotion $\quad 22$

$\begin{array}{ll}\text { Culturally Based Solution } & 23\end{array}$

Cultural Intervention Model 25

$\begin{array}{ll}\text { Pacific Island Model } & 28\end{array}$

$\begin{array}{ll}\text { Conclusion } & 33\end{array}$ 


\section{Abstract:}

In an already challenging environment, the Western diet has introduced noncommunicable diseases (NCD) such as diabetes and cardiovascular disease to the Pacific Islands (PIC). Without modern medicine, many of these regions, including Melanesia, Micronesia, and Polynesia are ill equipped to handle the long-term effects of these noncommunicable diseases. A high percentage of the Pacific Island population is obese and overweight; and the Islands are struggling to combat the epidemic. Many programs and proposals have been implemented, such as changes in trade policy, local activism, and government modifications, but there has been no evidence of a decline in noncommunicable diseases. There is still a significant amount to be done. I argue that culturally relevant approaches in the Pacific Islands, modeled after a Native American program, could prove to be an effective solution to positive dietary changes.

\section{Introduction:}

Europeans colonized the Pacific Islands first, followed by the Japanese; after World War II the United States occupied the islands. Today, only American Samoa is a U.S. territory. Many islands are now independent, and some, such as, American Samoa and the French Polynesia Islands, are still territories of foreign countries. Due to foreign occupation, there has been significant change in the Pacific Island's diet over the last fifty years. As the islands modernized and started developing urban areas, the diet of the people shifted. Instead of eating traditional foods, the islanders turned to cheap imported, processed foods that were high in fats and carbohydrates. The link between 
modernization, globalization, and obesity has been empirically documented. ${ }^{1} \mathrm{~A}$ comparative study was conducted between American and Western Samoans. The American Samoans lived a more modern lifestyle and their average body mass index (BMI) was 35.2 compared to Western Samoans of 30.3. A similar study in Papua New Guinea found that those living a modern lifestyle had less physical activity and a higher BMI. ${ }^{2}$ While malnourishment still exceeds obesity in underdeveloped countries, countries in developmental transition have seen a shift to a higher prevalence of obesity compared to undernourishment. This is an issue that plagues the world and the Pacific Islands have paid a price for modernizing their diet.

Micronesia, a province of the Pacific Islands, is a clear example of modernization and dietary changes in the islands. The Pacific Islander's original diet consisted of taro, breadfruit, yams, coconut, arrowroot, bananas, and seafood. When the Spanish came they introduced maize, cassava, sweet potatoes, chicken and pork. The Japanese also introduced rice. Even after the introduction of many new foods, the health of the Pacific Island population remained strong. Many new foods were introduced to the islands, but the PICs were still only consuming whole, unprocessed foods. In the 1940's after World War II, the U.S. Navy conducted a survey and found virtually no obesity, hypertension, or diabetes among the population. Dietary changes began when the United States occupied Micronesia. Beginning in the 1960's and 1970's when the islands started to receive food aid from the United States, the Pacific Island's diet transitioned to

\footnotetext{
1. Cassels, Susan. "Overweight in the Pacific: links between foreign dependence, global food trade, and obesity in Federated States of Micronesia." Globalization and Health 10 no. 2 (2006). http://globalizationandhealth.biomedcentral.com/articles/10.1186/1744-8603-2-10
}

2. Ibid., 4. 
predominantly rice and imported foods. The United States Department of Agriculture (USDA) gave food to Micronesia through the Supplementary Feeding program.

Children's lunches consisted of rice and tinned food. Their intentions were most likely in the right place, but the long-term effects of the program were not considered. By the 1980 's there was an increase in the consumption of sugar and sweet foods. ${ }^{3}$ Today Micronesia's diet mainly consists of rice, wheat flour, sugar, refined foods, and fatty meats, and as a result many islands have high obesity and diabetes rates, such as Yap, a state of the Federal States of Micronesia (FSM). $63-80 \%$ of the adults and $20.5-33.8 \%$ of children are over weight or obese and $23 \%$ of the adult population has diabetes. ${ }^{4}$ The local governments and the global community have started to address the dietary risk factors. After many years of an inadequate diet, a large portion of the population is facing the consequences of processed, western diet and sedentary lifestyle.

\section{Current Health:}

Non-communicable diseases influence the daily lives of individuals from a health and quality of life standpoint. Many people that are significantly over weight struggle to carry out daily tasks such as house hold chores, walking up steps, etc. A number of studies have identified the prevalence of the diabetes in the PICs. The World Health Organization (WHO) has also done a number of surveys among the Pacific Islands. Below is a summarized table of information collected from a variety of sources. The group sample size are from 473-4422. The age range varies from 15 and above. The three

3. Ibid., 3-4.

4. Ichiho, H., Yurow, J., Aiaoto, N. "An Assessment of Non-Communicable Diseases, Diabetes, and Related Risk Factors in the Federated States of Micronesia, State of Yap: A Systems Perspective." Hawai'i Journal of Medicine \& Public Health 72, no. 5 (2013): 57-67. http://www.ncbi.nlm.nih.gov/pmc/articles/PMC3689458/ 
methods of diagnosis include fasting capillary blood glucose, fasting blood glucose, and fasting venous glucose.

\begin{tabular}{|l|l|l|l|l|}
\hline Country & Year of Survey & Sample Size & Age Range & $\begin{array}{l}\text { Diabetes } \\
\text { Prevalence (\%) }\end{array}$ \\
\hline $\begin{array}{l}\text { American } \\
\text { Samoa }\end{array}$ & 2004 & 2072 & $25-64$ & 47.3 \\
\hline Cooks Islands & $2003-2004$ & 1870 & $25-64$ & 23.6 \\
\hline Fiji & 2002 & 2277 & $25-64$ & 16.0 \\
\hline $\begin{array}{l}\text { French } \\
\text { Polynesia }\end{array}$ & 2010 & 3469 & $18-64$ & 7.3 \\
\hline FSM & 2002 & 1638 & $25-64$ & 32.1 \\
\hline Kiribati & $2004-2006$ & 1146 & $25-64$ & 28.1 \\
\hline $\begin{array}{l}\text { Marshall } \\
\text { Islands }\end{array}$ & 2002 & 994 & $15-64$ & 19.6 \\
\hline $\begin{array}{l}\text { Nauru } \\
\text { Niue }\end{array}$ & 2004 & 883 & $15-64$ & $16.2(15-24)$ \\
\hline $\begin{array}{l}\text { Papa New } \\
\text { Guinea }\end{array}$ & $2007-2008$ & 2944 & 15 and up & 38.4 \\
\hline $\begin{array}{l}\text { Solomon } \\
\text { Islands }\end{array}$ & $2005-2006$ & 950 & $15-64$ & 14.4 \\
\hline Samoa & 2002 & 2817 & $25-64$ & 13.5 \\
\hline Tonga & 2004 & 453 & $25-64$ & 22.1 \\
\hline Tokelau & 2005 & 573 & $25-64$ & 16.4 \\
\hline Vanutau & 2011 & 4422 & $15-64$ & 33.6 \\
\hline $\begin{array}{l}\text { Wallis and } \\
\text { Futuna }\end{array}$ & 2010 & $25-64$ & 21.2 \\
\hline Tab & & $25-64$ & 17.5 \\
\hline
\end{tabular}

Table 1. Represents the diabetes prevalence rates in a number of Islands. ${ }^{5}$

To put these values into context, the prevalence of diabetes in the United States is 9.3 percent according to the Center of Disease Control and Prevention. All prevalence rates above, except one, exceed America's diabetes prevalence rate. There is frequently a concern in America regarding obesity and diabetes and the health costs associated with

5. Tin, S., Lee, C., Colagiuri, R. "A profile of diabetes in Pacific Island Countries and Territories." Elsevier: Diabetes Research and Clinical Practice 107 (2015): 233-246. http://www.sciencedirect.com.echo.louisville.edu/science/article/pii/S0168822714004707 
these diseases, therefore it is clear this issue in the PICs demands significant attention. It is also important to note that many cases of diabetes go untreated and many people are considered pre-diabetic. According to the Obesity Action Coalition, obese people are 3-7 times more likely to have type II diabetes, and 20 times more likely if they have a BMI over $35 .{ }^{6}$ Therefore it is important to assess the obesity rate of the Pacific Islands; these statistics are shown below.

\begin{tabular}{|l|l|}
\hline Countries & Obesity $(\boldsymbol{\%})$ \\
\hline Cooks Islands & $50.8 \%$ \\
\hline Paula & $47.6 \%$ \\
\hline Nauru & $45.6 \%$ \\
\hline Samoa & $43.3 \%$ \\
\hline Tonga & $43.3 \%$ \\
\hline Niue & $43.2 \%$ \\
\hline Marshall Islands & $42.8 \%$ \\
\hline Kiribati & $40.6 \%$ \\
\hline Tuvalu & $40.3 \%$ \\
\hline
\end{tabular}

Table 2. Obesity Rates in Pacific Islands ${ }^{7}$

The majority of islands have obesity rates between $35-50 \%$ according to WHO.

Due to many people being obese and having diabetes, a substantial amount of the population have other health complications associated with these diseases such as, retinopathy, resulting in blindness; microalbuminuria, damage of the kidneys; and amputations. Below is a chart showing the percent of complications on three of the Islands.

6. Rogers, Joanne Z. and Still, Christopher D. "Obesity and Type 2 Diabetes." Obesity Action Coalition. Accessed February 20, 2016. http://www.obesityaction.org/wp-content/uploads/Diabetes.pdf

7. Meera Senthilingam. "How paraside became the fattest place in the world." Cable News Network, 2015. http://www.cnn.com/2015/05/01/health/pacific-islands-obesity 


\begin{tabular}{|l|l|l|l|}
\hline Countries & Microalbuminuria & Retinopathy & $\begin{array}{l}\text { Abnormal Foot } \\
\text { Sensation }\end{array}$ \\
\hline Nauru & $71 \%$ & $69 \%$ & $30 \%$ \\
\hline Solomon Islands & $36 \%$ & $40 \%$ & $23 \%$ \\
\hline Vanuatu & $51 \%$ & $42 \%$ & $19 \%$ \\
\hline
\end{tabular}

Table 3. Represents the prevalence of diabetes complications in Nauru, Solomon Islands, and Vanuatu. ${ }^{8}$

The percentage of diabetics suffering from additional complications is relatively high. There are many other countries with higher diabetes prevalence than the three countries listed above; therefore it is likely that many countries are suffering just as much, if not more, from diabetes complications as well.

\section{Current Challenges:}

\section{$\underline{\text { Health Care and Health Costs }}$}

With an increasing number of people developing NCDs, the health care system is struggling to meet patient needs. The Pacific Islands have had minimal success using preventative measures to reduce diabetes and obesity. They are equipped with comprehensive services for treating these diseases, ${ }^{9}$ but not everyone is able to receive these treatments due to a shortage of resources or patients' negligence. There are few diabetics who chose to practice self-care. Self-care in defined by: healthy eating, being physically active, monitoring of blood sugar, compliant with medications, good problem-

8. Tin, S., Kenilorea, G., Gadabu, E., Tasserei, J., Colagiuri, R. "The prevalence of diabetes complications and associated risk factors in Pacific Islands countries." Diabetes Research and Clinical Practice 103 (2014): 114-118. http://www.sciencedirect.com.echo.louisville.edu/science/article/pii/S016882271300363X $198 \mathrm{pg}$.

9. Roger Haden, Food Culture in the Pacific Islands (Santa Barbara, California: Greenwood Press, 2009) 
solving skills, healthy coping skills and risk-reduction behaviors. ${ }^{10}$ With a large percent of diabetics not practicing self-care, much of the burden is left on the health care system. Studies conducted in Nauru, Solomon Islands, and Vanuatu found that 41\%, 13\%, and $11 \%$ were treated with diet alone, respectively, oral anti-diabetics agents $49 \%, 82 \%$, and $83 \%$, respectively, and insulin $10 \%, 5 \%$, and $6 \%$, respectively. ${ }^{11}$ Oral anti-diabetic medications works to increase the body's production of insulin or make the insulin more effective, although in many cases the oral anti-diabetic agents are not enough to maintain appropriate blood glucose levels and prevent the onset of diabetic related complications. ${ }^{12}$ The percentage of diabetics in Nauru, Solomon Islands, and Vanuatu reaching their goals for blood pressure, cholesterol levels, and triglycerides never exceeded 55\% and many areas were in the $20-30 \%$ range. Overall, there is a lack of treatment and therefore a low percent of diabetics achieving their "self-care" health goals. It is also important to consider that almost all type II diabetes is reversible through proper diet and exercise.

The health costs associated with non-communicable diseases put a financial strain on both the health care system and the individual. A 2010 study in Vanuatu found that, on average, a patient with type II diabetes spends approximately \$410 USD on prescription medication, transportation, and special diet. ${ }^{13}$ The average income in Vanuatu as of 2014 was $\$ 3,160$ USD; therefore approximately $13 \%$ of income is spent on health care for

10. Shrivastava, S., Shrivastava, P., Ramasamy, J. "Roles of self-care in management of diabetes mellitus." Journal of Diabetes and Metabolic Disorder 12, no. 14 (2013). Accessed January 15, 2016. http://www.ncbi.nlm.nih.gov/pmc/articles/PMC3599009/

11. Tin, S., Kenilorea, G., Gadabu, E., Tasserei, J., Colagiuri, R. "The prevalence of diabetes complications and associated risk factors in Pacific Islands countries." Elsevier: Diabetes Research and Clinical Practice 103 (2014): 114-118. http://www.sciencedirect.com.echo.louisville.edu/science/article/pii/S016882271300363X

12. Gali Brashers-Krug, "Understanding Oral Diabetes Medications," Voice of the Diabetic, last modified October 2007, https://nfb.org/images/nfb/publications/vod/vod_22_4/vodfal0712.htm

13. Falconer D.G, Buckley A., and Colagirui, R. "Counting the cost of type 2 diabetes in Vanutau." Diabetes Research Clinical Practice. 87, no. 1 (2010): 92-7. http://www.ncbi.nlm.nih.gov/pubmed/19875191 
diabetes alone. ${ }^{14}$ The costs were significant for the health care system as well, but because poverty is prevalent in the Pacific Islands any additional costs to individuals are difficult to manage. For many developing and recently developed countries, health care systems have become accustomed to communicable diseases. Vaccinations and treatments for these diseases are common. Non-communicable diseases are a whole new field of medicine that is unfamiliar and difficult for health care systems to manage because in many cases non-communicable diseases require life long treatment and patient accountability. ${ }^{15}$ There is no data identifying how diabetes and other NCDs affect employment in the PICs, but is it important to note that NCDs account for $66.5 \%$ of the years people live with disabilities. ${ }^{16}$ Disabilities such as loss of vision or amputation, two disabilities commonly caused by diabetes, can make it difficult for people to maintain employment.

\section{Poverty, Population \& Food Security}

Many individuals in the PICs struggle to deal with health care costs because a reasonable portion of the population lives in poverty. The table below provides the poverty rate for many of the Pacific Islands.

\begin{tabular}{|l|l|}
\hline Country & Poverty Rate (\%) \\
\hline Timor- Leste & 49.9 \\
\hline Federal States of Micronesia & 31.4 \\
\hline
\end{tabular}

14. "Vanuatu." The World Bank, 2014. http://data.worldbank.org/country/vanuatu

15. Anderson, Ian. "The Economic Costs of Non-Communicable Diseases in the Pacific Islands." The World Bank. (2012) http://www.worldbank.org/content/dam/Worldbank/document/the-economic-costs-of-noncommunicablediseases-in-the-pacific-islands.pdf

16. Wilson, Catherine. "Diabetes Epidemic Threatens Development Gains in Pacific Islands." Inter Press Service. Feb. 11, 2015. http://www.ipsnews.net/2015/02/diabetes-epidemic-threatens-development-gains-in-pacificislands/ 


\begin{tabular}{|l|l|}
\hline Fiji & 31.0 \\
\hline Cooks Islands & 28.4 \\
\hline Papua New Guinea & 28 \\
\hline Samoa & 26.9 \\
\hline Tuvalu & 26.3 \\
\hline Palau & 24.9 \\
\hline
\end{tabular}

Table 4. Poverty Rates in Pacific Islands ${ }^{17}$

Research has shown that inadequate diet as well as obesity is linked to poverty. The Pacific Islands turn to imported foods because they are inexpensive but also calorie dense. Affordable, imported goods that many PIC individuals consume as staple foods include fatty meats and wheat flour. As the PICs have increased food imports they have become more reliant on the global economy. As a result the islands suffered during the global recession when food prices increased.

Poverty is only one of many factors effecting health of the Islands. The population growth occurring on the PICs has also been a contributing factor to food insecurity because the islands must supply more food for the growing population. The population of the Pacific Islands in the 2010 was 10.1 million people. The annual growth rate was 1.9\%. Table 5 identifies the projected populations for each province.

\begin{tabular}{|l|l|l|l|}
\hline Country & $\mathbf{2 0 3 0}$ & $\mathbf{2 0 3 5}$ & $\mathbf{2 0 5 0}$ \\
\hline Melanesia & $12,108,329$ & $13,134,695$ & $16,116,244$ \\
\hline Micronesia & 357,213 & 368,561 & 400,779 \\
\hline Polynesia & 339,382 & 347,410 & 363,866 \\
\hline Total & $12,803,711$ & $13,849,627$ & $16,879,149$ \\
\hline
\end{tabular}

Table 5. Projected populations in four main regions of PICs ${ }^{18}$

17. "Poverty and Employment in Asia and the Pacific." Asian Development Bank. October 27, 2015. http://www.adb.org/news/infographics/poverty-and-employment-asia-and-pacific

18. Ahmed, M., Maclean, J., Gerpacio, R., Sombilla, M. "Food Security and Climate Change in the Pacific Islands." Asian Development Bank. Accessed January 15, 2016. http://www.adb.org/sites/default/files/publication/29078/climate-change-food-security.pdf 
Emigration to surrounding nations, mainly New Zealand, has helped reduce population growth. For example, without emigration Samoa would have doubled its population of 183,000 people in 2010 to nearly 400,000 today. ${ }^{19}$ However, even with many people emigrating from the PICs the population growth and limited resources resulted in food insecurity. This food insecurity has forced people to look outside the islands for food. In 1942 when the Pacific Islands became involved in World War II, imported foods became common. ${ }^{20}$ Additionally, when the economy shifted from a tradecentered to a cash-centered economy, the PICs were able to make global trades that they were unable to make prior. The cash economy opened up many doors for the PICs to enter into global food trade. While this event was beneficial to economic growth, it fostered a long-term problem regarding highly processed food imports.

\section{$\underline{\text { Agriculture }}$}

Another factor influencing the PICs importation of staple foods as they struggle for food security concerns access to farmland. There is approximately 34 million hectares of forest, and 25 millions hectares are closed canopy forest that can be used commercially for logging and agriculture. ${ }^{21}$ Papua New Guinea (PNG), Fiji, Solomon Islands, and Vanuatu compose about $85-90 \%$ of the viable agricultural land. ${ }^{22}$ Many of the small

19. Ibid., 6 .

20. Roger Haden, Food Culture in the Pacific Islands (Santa Barbara, California: Greenwood Press, 2009), 200.

21. Ahmed, M., Maclean, J., Gerpacio, R., Sombilla, M. "Food Security and Climate Change in the Pacific Islands." Asian Development Bank. Accessed January 15, 2016.

http://www.adb.org/sites/default/files/publication/29078/climate-change-food-security.pdf pg 8.

22. Bell, Winnie F. "Organic Agriculture and Fair Trade in Pacific Island Countries." Food and Agriculture Organization of the United Nations. (2009). http://www.fao.org/3/a-ak356e.pdf 
islands have sandier soil and are limited in the variety of crops they are able to grow.

These islands generally turn to fisheries and the service industry for economic development rather than crop production. While some islands do not produce commercial crops, many people living in rural regions engage in subsistence agriculture. ${ }^{23}$

The traditional crops included coconut, breadfruit, pandanus (tree crops), taro, and other root crops. Sweet potato, limes and vegetables have become common crops as well. The largest commercial crop is coconut, followed by taro and sugarcane. ${ }^{24}$ Unfortunately, agricultural production has declined over the years due to a wide range of causes. The setbacks include land leasing for non-agricultural purposes, inadequate equipment, decline in fruit tree productivity, and depressed global food prices. Some countries have increased their crop production, but they have done it through increasing farmland rather than increased productivity per hectare.

\begin{tabular}{|l|l|l|l|l|l|l|}
\hline Countries & $\mathbf{1 9 6 0 s}$ & $\mathbf{1 9 7 0 s}$ & $\mathbf{1 9 8 0 s}$ & $\mathbf{1 9 9 0 - 1 9 9 4}$ & $\mathbf{1 9 9 5 - 1 9 9 9}$ & $\mathbf{2 0 0 0 - 2 0 0 8}$ \\
\hline $\begin{array}{l}\text { Cooks } \\
\text { Islands }\end{array}$ & 135.0 & 152.0 & 133.2 & 89.0 & 90.4 & 74.6 \\
\hline Fiji & 115.9 & 103.1 & 108.3 & 111.6 & 103.0 & 94.9 \\
\hline Kiribati & 135.7 & 119.2 & 120.9 & 90.4 & 102.0 & 104.8 \\
\hline FSM & & & & & 99.4 & 98.1 \\
\hline Nauru & 105.1 & 102.3 & 107.4 & 101.8 & 99.6 & 100.6 \\
\hline PNG & 100.3 & 105.8 & 105.7 & 100.6 & 99.4 & 96.6 \\
\hline Samoa & 128.4 & 120.6 & 133.0 & 91.6 & 100.8 & 101.3 \\
\hline $\begin{array}{l}\text { Solomon } \\
\text { Islands }\end{array}$ & 127.4 & 122.2 & 126.0 & 104.4 & 108.2 & 97.8 \\
\hline $\begin{array}{l}\text { Timor - } \\
\text { Leste }\end{array}$ & 83.0 & 90.8 & 97.9 & 106.8 & 101.4 & 93.8 \\
\hline Tonga & 145.8 & 131.0 & 112.5 & 106.6 & 97.0 & 101.3 \\
\hline Tuvalu & 143.9 & 103.9 & 108.9 & 97.6 & 92.0 & 105.9 \\
\hline Vanuatu & 174.2 & 152.1 & 142.1 & 119.4 & 115.8 & 92.5 \\
\hline
\end{tabular}

23. Ahmed, M., Maclean, J., Gerpacio, R., Sombilla, M. "Food Security and Climate Change in the Pacific Islands." Asian Development Bank. Accessed January 15, 2016.

http://www.adb.org/sites/default/files/publication/29078/climate-change-food-security.pdf

24. Ibid., 10 . 
Table 6. Crop production per person over the years in various islands ${ }^{25}$

\section{$\underline{\text { Fisheries }}$}

Fishing has always been a main source of protein for the PICs due the geography of the islands and a wide variety of seafood. One prominent fish industry is tuna. The 200-mile zone surrounding the islands, the exclusive economic zone (EEZ), supplies more than $30 \%$ percent of the world's tuna. Tuna processing and fishing provides approximately $25 \%$ of GDP, and employs thousands of individuals in several of the PICs. Unfortunately, many islands only receive a small portion of the \$2 billion USD tuna industry in the EEZ. For example, the FSM receive $\$ 170$ million USD generated from tuna fishing rights between 1979 and 2000. Annually that is only 8 million dollars. This revenue has contributed $20-30 \%$ of the domestic revenue, but only 8 million dollars a year out of 2 billion dollar industry is slim. The license fees for fishing in the EEZ by foreign countries has increased by $400 \%$ in the recent years, but the PICs could increase revenue and employment if they chose to harvest more tuna themselves rather than outsourcing the industry to foreign countries. The licensing fees were found to be $3.5 \%$ of the total catch revenue. ${ }^{26,27}$ Foreign nations are capitalizing from the tuna industry despite the PICs direct control over the islands. Not only could increasing the tuna industry within the PICs help the economy, but it could also improve the health of the islanders. Seafood contains protein, essential fatty acids, vitamins, and minerals. If the PICs took

25. Ibid., 12.

26. Bell, Johann D., "Diversifying the use of tuna to improve food security and public health in Pacific Island countries and territories," Marine Policy 51 (2015): 584 -591

http://www.sciencedirect.com.echo.louisville.edu/science/article/pii/S0308597X1400267X

27. Cassels, Susan. "Overweight in the Pacific: links between foreign dependence, global food trade, and obesity in Federated States of Micronesia." Globalization and Health 10 no. 2 (2006). http://globalizationandhealth.biomedcentral.com/articles/10.1186/1744-8603-2-10 
advantage of the industry, there would be an increased availability of tuna. Whereas today, most of the tuna harvested in the PICs is distributed outside the islands.

\section{$\underline{\text { Environment }}$}

The environment is a contributing factor to both limited crop production and inconsistency in the fishing industry. The location of the PICs makes them vulnerable to many natural disasters such as cyclones, hurricanes, and tsunamis. The result of these disasters leave the farmland is poor condition. For example, in April 2014 a cyclone struck islands in the southwest pacific, including Sudest. The heavy rainfall and winds up to $160 \mathrm{mph}$ left much of the vegetation such as the coconut palms and the yam crops uprooted and damaged. Many individual gardens were also destroyed, and this left many communities without a means of a diet. ${ }^{28}$ Cyclone Gene lost Fiji $\$ 32$ million USD in agriculture, infrastructure, utilities, and properties. Ten years prior, in 1998 Fiji lost 75 million dollars in sugar cane crops during the El Nino southern Oscillation (ENSO). In February 2016, another cyclone plagued the islands with significant damaged. El Nino is an irregular variation in winds and sea surface temperature in the Pacific Island seas. The ENSO also plays a role in the location of the skipjack tuna population. ${ }^{29}$ Therefore, frequent occurrence of natural disasters and the ENSO events pose a threat to the stability of the agriculture and fishing industries.

28. Goulding, W., Moss, P., McAlpine, C.A."Cascading effects of cyclones on the biodiversity of Southwest Pacific islands." Elsevier: Biological Conservation 193 (2016): 143-152. http://www.sciencedirect.com.echo.louisville.edu/science/article/pii/S0006320715301701

29. Ahmed, M., Maclean, J., Gerpacio, R., Sombilla, M. "Food Security and Climate Change in the Pacific Islands." Asian Development Bank. Accessed January 15, 2016.

http://www.adb.org/sites/default/files/publication/29078/climate-change-food-security.pdf 
The ciguatera fish poisoning has also limited the fishing industry. From the time span of 1973-1983 compare to $1988-2008$ there has been a $60 \%$ increase in the annual incidence. The ciguatera is a natural toxin that comes from a microalgae bloom. The degrading of reefs and climate change has likely causes the increase in the incidence of ciguatera. ${ }^{30}$ The southern Pacific Islands have experienced a $0.8 \mathrm{C}$ increase in average temperature and $15 \%$ drier temperature. The central equatorial islands on the other hand have seen $30 \%$ more rain and $0.6 \mathrm{C}$ increase in temperature. In 2007, Fiji experienced a $200 \%$ increase in rainfall. There have been small changes observed due to climate changes, such as shift in blooming season and beginning decline in mangroves, but longterm effects on food security have been anticipated for the PICs. ${ }^{31}$

\section{Urban vs. Rural Living}

The population growth of urban living has surpassed rural living for three decades now. Urbanization in the PICs first began in the 1960's. Urban living in the islands is describes as, " rural villages within a modernized urban setting that exhibits the physical, social, and cultural characteristics of traditional rural villages, including their ethnic and kinship composition." The urban movement started due to increasing population, rather than economic growth, which is when most other countries experience urbanization. This is problematic because as people move to urban locations there are limited employment opportunities due to the lack of economic growth. In the PICs, this has resulted in some

30. Skinner, M., Brewer, T., Lewis, R. "Ciguatera Fish Poisoning in the Pacific Islands." PLoS Neglected Tropical Diseases 5 no. 12 (2011): 1-18. http://www.ncbi.nlm.nih.gov/pmc/articles/PMC3236724/

31. Ahmed, M., Maclean, J., Gerpacio, R., Sombilla, M. "Food Security and Climate Change in the Pacific Islands." Asian Development Bank. Accessed January 15, 2016.

http://www.adb.org/sites/default/files/publication/29078/climate-change-food-security.pdf 
urban areas with significantly higher poverty rates compared to rural areas. Specifically, this trend can be observed in Vanuatu, Tuvalu, Solomon Islands, Cooks Islands, and Kiribati. With a growing population and limited land some urban villages are seeing population densities similar to those in large Asian cities. ${ }^{32}$

The majority of the population migrating from rural to urban areas is young adults. Young adults are currently having the hardest time finding work. For example, in Honiara, the capital of the Solomon Islands, approximately $80 \%$ of the youth are unemployed. ${ }^{33}$ Due to urbanization, as well as additional factors such as irregular weather patterns, some islands have seen a shift from agriculture to the service industry. Inadequate access to water, quality food, and health care, as well as limited space to partake in physical activity, are concerns taken for the poor urban community. The percent of the Island populations living in urban areas is listed below. ${ }^{34}$

\begin{tabular}{|l|l|}
\hline $\begin{array}{l}\text { Pacific Island } \\
\text { Countries }\end{array}$ & \% Urban Population \\
\hline Fiji & $51 \%$ \\
\hline Papua New Guinea & $13 \%$ \\
\hline Solomon Islands & $20 \%$ \\
\hline Vanuatu & $24 \%$ \\
\hline
\end{tabular}

32. Ibid., 7.

33. Ofotalau, Alison. "Beating Unemployment in the Solomon Islands." The World Bank. Jan. 29, 2013. http://blogs.worldbank.org/eastasiapacific/beating-unemployment-in-the-solomon-islands

34. "The State of Pacific Towns and Cities." Asian Development Bank (2012). http://www10.iadb.org/intal/intalcdi/PE/2012/07773.pdf 


\begin{tabular}{|l|l|}
\hline Cooks Islands & $72 \%$ \\
\hline Samoa & $21 \%$ \\
\hline Tonga & $23 \%$ \\
\hline Tuvalu & $47 \%$ \\
\hline FSM & $22 \%$ \\
\hline Kiribati & $44 \%$ \\
\hline Marshall Islands & $65 \%$ \\
\hline Nauru & $100 \%$ \\
\hline Palau & $77 \%$ \\
\hline
\end{tabular}

Table 6. Percent of Island populations living in an urban setting ${ }^{35}$

\section{$\underline{\text { Cultural Set Backs }}$}

In the PICs, there is a cultural perception that imported foods are superior to local foods because they come from wealthy countries. Unfortunately, some of the imported foods the PICs receive are foods that are unpopular in other countries due to questionable nutrients and fat content. One example is mutton flap that contains 40 grams of fat per 100 grams of meat. ${ }^{36}$ In addition to the appeal of imported food, "eating until one cannot eat any more is a traditional sign of well-being." ${ }^{37}$ Foods such as pork fat and coconut cream are considered a delicacy. In the past these foods were not available on a daily basis, but now they are. The consumption of these foods daily puts individuals at risk for NCDs. ${ }^{38}$ Managing a healthy diet is a difficult task, but cultural barriers make this more challenging.

\section{Current Interventions:}

35. Ibid., 7.

36. Watson, K., and Treanor, S. "How mutton flaps are killing Tonga." BBC News. January 18, 2016. http://www.bbc.com/news/magazine-35346493

37. Roger Haden, Food Culture in the Pacific Islands (Santa Barbara, California: Greenwood Press, 2009), 201.

38. Ibid., 202. 
In 2007 a comprehensive analysis of current and future interventions was generated for the World Health Organization's Western Pacific Regional office. The current and proposed interventions included sin taxation, health food subsidies, food labeling, food policy changes, health promotion, limitations on youth food consumption and physical activity and nutrition programs in schools. Currently, health promotion campaigns, health education, school lunch programs, and physical activity programs have been implemented in some Pacific Islands. Is it important to note that each country requires different levels of intervention, therefore regional and individual interventions, with the help of the Western Pacific Regional Office (WPRO), was recommended.

To analyze different interventions the following questions of each action were assessed: Is it feasible? Is it sustainable? Does it impact the groups reported as obese? Does it have side effects? Is it acceptable? The analysis found that regulating youth food consumption and advertisement restrictions were not interventions that would be workable or successfully implemented. Advertisement restrictions require evidence that the product has negative side effects or is otherwise considered discriminatory, and carrying out additional research is not practical. Food labeling was not seen as a workable intervention because research shows that food labeling generally does not have a significant impact on food consumption, especially if people are uneducated in basic nutrition. The most workable solutions include specific guidelines for imported foods, taxation, health promotion, physical activity programs, and school lunch programs. ${ }^{39}$ All of which have already been implemented in some way. Listed below are examples of

39. Clarke, D., McKenzie, T. "Legislative Intervention to Prevent and Decrease Obesity in Pacific Island Countries," Allen \& Clark, Policy and Regulatory Specialists Limited, June, 182007. http://www.wpro.who.int/nutrition/documents/docs/Finalobesityreport.pdf?ua=1 
food policy changes, food market changes (i.e. fisheries), sin taxation, and health promotion in schools.

\section{Food Policy:}

Meats with a high percent fat content are distributed in many PICs. In Samoa, Fiji, and Tonga policy makers decided to intervene. Samoa banned the import of turkey tail, Fiji banned the import of lamb/mutton flap, and Tonga put restrictions on the distribution of mutton flap. Both lamb/mutton flap and turkey tail are both considered "food dumping" items. Food dumping involved food aid or food trade of inadequate foods that are otherwise unwanted. There were mixed responses from citizens, although some did state that the bans and regulations raised awareness for healthy food consumptions and this gap in the meat industry could be an opportunity for local meat production and/or fisheries. These regulations and bans, mainly prompted by the Ministry of Health, took a long time to be considered and put into action. An analysis of these three policy changes found that advocacy and contextualization are key to policy change in the PICs. In addition to the policy changes, reducing import tariffs on fruits and vegetables, maintaining high tariffs on unhealthy imported foods, and reducing the amount of unhealthy imported foods were all suggested as future policy changes. The drawback to the policy changes included concern regarding the World Trade Organization and the countries, such as the United States, Australia, and New Zealand that export these meats. Many industries do not comply with regulations and create barriers for policy change. The study has been unable to identify if the average intake of fatty meats has been reduced or if other fatty meats have been substituted for 
mutton/lamb flap and turkey tail. ${ }^{40}$ According to WHO Western Pacific Regional Office, the ban in Fiji has not been successful because the foods can be replaced with equally unhealthy products. A more effective method would be to set composition standards for all meats for them to be legally imported. This method has proven effective for Ghana. ${ }^{41}$ II. Sin Taxation:

Around half of all PICs have adopted sin taxes on sugar drinks. The Cook Islands for example implemented a tax of NZ\$0.38 per can of Coke, which equates to NZ\$9.80 per $1 \mathrm{~kg}$ of sugar in soft drinks. This tax is the highest of all taxes in the PICs. The island of Tokelau is a small island of only 1,600 people, and it was able to ban the importation and consumption of soft drinks all together. Therefore, they have seen a significant decrease in importation and consumption. The way in which the tax is implemented is a key factor in if the taxation will improve health. The factors of implementation include, "communication of a clear health goal, using excise tax, taxing on volume or sugar content, introducing an adequate tax rate (e.g. 20+\%), investing revenue back into health, and ensuring affordable healthy alternative beverages." There are several factors that make this process detailed as well as difficult. There is no current data as to whether the taxation has improved health but similar taxes have been implemented in Mexico and

40. Thow, A., Swinburn, B., Colagiuri, S., Mere, D., Quested, C., Vivili, P., Leeder, S. "Trade and food policy: Case studies from three Pacific Island countries." Food Policy. 35 (2010): 556-564. http://www.sciencedirect.com.echo.louisville.edu/science/article/pii/S0306919210000771

41. Clarke, D., McKenzie, T. "Legislative Intervention to Prevent and Decrease Obesity in Pacific Island Countries," Allen \& Clark, Policy and Regulatory Specialists Limited, June, 182007.

http://www.wpro.who.int/nutrition/documents/docs/Finalobesityreport.pdf?ua=1 
have shown a decrease in the purchase of sweetened beverages by $12 \%$ after one year of implementation. $^{42}$

III. Fisheries:

A recent study projected the amounts of tuna necessary to fulfill each island's daily protein intake. The study showed that many islands do not have the tuna supply to keep up with the growing population, but there are many ways that the tuna supply can be increased. The two main suggestions included the use of near-shore-fish aggregating devices (FAD) and assisting small-scale tuna vessels. By using the FADs and minimizing interaction and conflict between commercial and small local vessels, the smaller vessels have potential to increase their tuna catch. Additionally, training in FADs and catch handling would be provided. For the inland populations, canned tuna could be distributed and would ensure a safe source of protein. ${ }^{43}$ This proposal has not yet been put into action therefore there is no way to assess the proposal's success.

III. Health Promotion:

Fiji National University School of Medicine and Nursing School along with Deakin University in New Zealand started the Pacific Research Center for the Prevention of Obesity and Non-Communicable Diseases (C-POND). The two programs comprising C-POND are Obesity Prevention in Communities (OPIC) and Translation Research for Obesity Prevention In Communities. The first OPIC project involved school interventions for students ages 13-18 in Fiji, Tonga, and New Zealand. The main objectives of the

42. McDonald, Andrea. "What the Pacific \& Mexico can tell us about soft drink taxes and public health." University of Otago. Accessed February 20, 2016. https://blogs.otago.ac.nz/pubhealthexpert/2015/08/18/what-thepacific-mexico-can-tell-us-about-soft-drink-taxes-and-public-health/

43. Bell, Johann D., "Diversifying the use of tuna to improve food security and public health in Pacific Island countries and territories," Marine Policy 51 (2015): 584 -591 http://www.sciencedirect.com.echo.louisville.edu/science/article/pii/S0308597X1400267X 
program were to reduce sugar beverages, increase percent of children eating breakfast, increasing physical activity, decrease television and increase quality of food at school. While there was success in some of these subject matters, there was only a small change in the students' body mass index (BMI) over the course of the project. To improve results, the project will be followed up by more intervention and interventions beyond a school setting. ${ }^{44}$

The food policy and taxation are both methods of regulation. Both of these methods require overcoming industrial barriers and legislative processes that stunt the progression of interventions. While these regulations are important interventions, there is a limit to how much the government can regulate the food system; therefore regulation must be a supplemental intervention if significant change in NCDs is desired. The fishing industry and health and wellness programs are opportunities to improve health. There is also significant opportunity to implement community-based interventions that encourage active participation.

\section{Culturally-Based Solution}

There are a number of factors, such as history, landscape, climate change, urbanization, and population growth that have led to the PICs current food situation and health status. There are a number of solutions that would benefit the PICs significantly, but some solutions are difficult to implement and others need to be incorporated with supplemental interventions. For a solution to be effective and have a long-term impact,

44. Tuiketei, T., Snowdon, W., Waqa, G., Kremer, P., Schultz, J., and Vanualailai, N. "Pacific Obesity Prevention in Communities Project Fiji Country Report." Fiji School of Medicine and Deakin University. August 2010. http://www.fsm.ac.fj/files/Country\%20OPIC\%20Fiji\%20report\%20with\%20cover\%20FINAL.pdf 
the people of the Pacific Islands must take the lead. Most current solutions are promoting health and a stronger economy. While these are factors that most likely appeal to the population, it is clearly not enough incentive to prevent and/or decline the prevalence of NCDs. Unfortunately, studies have found that successful treatment in adults, who have chosen their intervention plan, only reduce their body weight by $10 \%$ and most regain the weight back a few years following the treatment. ${ }^{45}$ Non-communicable diseases are largely a result of human behavior, which makes them even more difficult to treat. Food choices go far beyond the nutritional make up of a food. For instance, studies have found that children choose foods that adults they admire eat and that their favorite fictional characters eat. When people go out to eat, they not only consider the quality of food, they also consider the atmosphere, service, location and cost. ${ }^{46}$ Food embodies experience, emotion, and health. Groups also make an impact on our food choices. We tend to form similar habits, tastes, and distastes for food our peers consume. ${ }^{47}$ Cultural communities are a direct example of this finding. Therefore a new motivating factor could be beneficial to adjusting the lifestyles of people in the PICs. The Pacific Islands have a rich culture that many Islanders still identify with today. The traditional lifestyle, as well as their diet, was a healthy way of living. Using cultural influence as a basis of motivation could encourage more individuals to change their way of life and improve their health.

45. Stice, E., Shaw, H., Marti, C. "A Meta-Analytic Review of Obesity Prevention Programs for Children and Adolescents: The Skinny on Interventions that Work." Psychological Bulletin. 132, no. 5 (2006): 667-691. http://www.ncbi.nlm.nih.gov/pmc/articles/PMC1876697/

46. Almerico, Gina M. "Food and Identity: Food Studies, cultural, and personal identity." Journal of International Business and Cultural Studies. no. 8 (2014) http://www.aabri.com/manuscripts/141797.pdf

47. Ibid., 4. 
The cultivation and preparation of food are two key areas that are cherished by many cultures, including the Pacific Islands. The traditional diet is based around whole fruits, vegetables and seafood, which provide a well balanced diet. Promoting traditional food and the cultivation of these foods could not only change their diet and physical activity patterns, but it could renew Pacific Island traditions and build community among the people.

\section{Cultural Intervention Model}

In Michael Pollan's documentary Cooked he discusses a study of the Aborigines people, an indigenous group in Australia. In the study, a group of Aborigines people who had changed to a modern diet and lifestyle were convinced to switch back to their traditional diet. The results show significant improvement in health. ${ }^{48}$ The Native American community has also used this strategy to promote health with the support of the Center of Disease Control and Prevention. Similarly, the Native American model provides a foundation for a potential program in the Pacific Islands.

The Native American population has struggled for many decades with health disparities and NCDs. These issues were brought on by the disruption of both land and culture, as similar case for the Pacific Islands. For instance, the Pima-Maricopa and Akimel O'odham tribes' source of water in Arizona was dammed and redirected for commercial farming leaving them without a reliable source of water in a dry environment. As a result, these tribes were forced to find food beyond their farmlands. As the issue escalated a program in 1997 was set up to reduce diabetes in the youth 
population the students were educated through books that incorporated health education as well as traditional and cultural knowledge a long side medicine. The program showed success and helped improve glucose levels, blood pressure, and the prevalence of End Stage Renal Disease (ESRD). In 2004, the Native diabetes wellness program started, focusing on tribal-driven, community-based approaches, and in 2008 the Traditional Foods Project started. This program ran for 6 years from 2008 to 2014 and was commissioned by the Center of Disease Control (CDC) Office of Minority Health and Health Equity. The goal of the project was to reclaim food systems for health promotion and prevention of chronic illness including diabetes. The aims of the project are as follows:

1) Support sustainable and evaluable ecologic approaches to reclaim traditional foods and physical activity; 2) encourage local practices that increase access to local foods and physical activity; 3 ) revive and create stories of healthy traditional ways to be remembered, retold, and talked about in homes, schools, and communities; and 4) engage community members to track success, participate in health promotion activities, explore diabetes in context with community history, and share stories of hope.

It is important to note that there is an emphasis placed on cultural incorporation because it is something with which the people identify. The foundation of the program is not based solely on nutrition; it is also based on food sovereignty and culture.

The rate of diabetics among the general Native American population is still rising on average, but from 2006 to 2013 diabetes prevalence increased $0.8 \%$ compared to $2.2 \%$ from 2001 to 2005. Between 1995 and 206 incidence of ESRD decreased by $27.7 \%$, the largest decline among any ethnic group, and from 2000 to 2011 ESRD diagnosis due to diabetes decreased by $43 \%$. Among the youth, diabetes prevalence has not increased since 2006. According to Mark Trahant, a member the Shoshone Bannock Tribe and a 
journalist, these statistics are a result of tribally designed program and government funding. ${ }^{49}$

A recent report from the CDC identified the necessary elements that were implemented to make the Traditional Food Project successful. In this dynamic program qualitative data was collected through tribal presentations, monthly calls, and annual meetings to understand the projects maturation, development, accomplishments, barriers and necessary adaptions. Each local program was allocated $\$ 100,000$ USD per year. The assessment of the program highlighted specific requirements for a successful outcome. These include:

1. Proper sustainment and utilization of land protected by the government.

2. Workshops for cooking, hunting, gathering, fishing, preservation of food, and environmental stewardship to ensure the land will be used efficiently.

3. Reclaiming foods specific to landscape, history, and culture.

4. Using personal stories to encourage the greater Native American population to reclaim traditional foods.

5. Respecting and using traditional knowledge to cultivate the land and cook.

6. Aligning cultural values with health views.

7. Utilizing elders as teachers. Elders act as advisors to help guide program, teaching younger generations traditional practices and traditional language.

8. Using traditional foods to fuel conversations about health such as, conversations about growing, harvesting, and food preparation with the nutritional value of the foods. 50

49. Trahant, Mark. "Reversing Diabetes Rates in Indian Country." Indian Country Today Media Network. May 19, 2016. http://indiancountrytodaymedianetwork.com/2015/05/19/reversing-diabetes-rates-indian-country160402 
9. Using seasonal food calendars, posters, and lesson plans.

10. Engaging in traditional games, dances, and discussion sessions.

11. Emphasizing education through recipes, cooking, and food preparation. i.e. food demonstrations, taste test in schools and clubs.

12. Serving traditional meals at schools.

13. Educating community on food sovereignty

14. Providing families with meal plans.

15. Community assessment of needs using focus groups, interviews and surveys.

16. Assisting in the implementation from government.

17. Continuation of efforts following the program.

\section{$\underline{\text { Pacific Island Model }}$}

The Pacific Island culture has much to offer in building community and improving health. The most direct correlation between culture and health is diet. The traditional diet of the islands mainly consisted of starchy root vegetables, starchy nonroot vegetables, fruits, meats, fish and seafood. The main starchy root vegetables include taro, yams and cassava. Taro was the mostly widely distributed food in the ancient world is a source of zinc, protein, iron calcium, niacin, and carbohydrates. Taro symbolizes abundance and hospitality. Today Taro is relatively expensive because it is not grown like it once was. Taro can grow in wet and swampy conditions. Today, cassava is more popular because it is a cheaper option. Dried cassava can be made into tapioca and it can

50. Satterfield, D., DeBruyn, L., Santos, M., Alonso, L., Frank, M. "Health Promotion and Diabetes Prevention in American Indian and Alaskan Native Communities - Traditional Foods Project 2008-2014." Center for Disease Control and Prevention. 65, no. 1 (2016): 4-10.

http://www.cdc.gov/mmwr/volumes/65/su/su6501a3.htm 
tolerate poor soil and rainfall. Sago and arrowhead are the two main non- root vegetables. To access sago it must be extracted from a palm tree and $600 \mathrm{lb}$. can be extracted from an old tree at one time. The most common fruits are coconut and plantains. Fruit is available all year around and it is mainly harvested between December and March. Coconut is seen as the most important of all island crops, and it is still an important cash crop. Coconut is versatile in the PIC diet. People use coconut milk and the main cooking liquid, they drink coconut water daily, and the fruit itself can be used eaten raw or cooked. Pork is the main animal protein in the PICs, although low-grade chicken and other meats are now being consumed regularly. A wide range of seafood and fish, including tuna, snapper, and dolphin fish, are all consumed and are a great source of protein. In the Tamotu Islands, fisherman still use traditional methods, including diving with funnel shaped nets to snare fish. The most traditional cooking method in the islands is a style called umu. This was an underground cooking method where wrapped food was cooked on heated rocks. ${ }^{51}$ It is clear that similar to the Native American culture, the culture of the Pacific Islands has much to offer. It offers a well balanced diet, adequate cooking methods, and encourages participation in physical activities. Using the methods detailed above, the culture can be revived in the PIC's. The guidelines above can be the basis for a Pacific Island Tradition Food Program and adjustments can be made to better suit the Pacific Island population. The CDC oversaw the operations of the Tradition Food Program. It would be beneficial for the WHO Western Pacific Regional Office to oversee a Tradition Food program (TFP) in the PICs, but the program could be successful operating on an individual island basis. The current interventions suggested and implemented in the PICs

51. Roger Haden, Food Culture in the Pacific Islands (Santa Barbara, California: Greenwood Press, 2009, pg. 57 90. 
would strongly supplement the Traditional Food Project. For instance, there are already many school programs promoting wellness and healthier lunches. These programs could be adjusted to education students about healthy traditional foods, and the lunches could be made from local foods.

Taxation and subsidies could tax unhealthy imported foods, subsidize foods such as taro and yams that are currently considered luxury items because of their price, but were once stable foods. The food policy changes are discouraging non-traditional food such as the turkey tail and mutton flap. This provides an opportunity for other meat production, such as pork, which has been a source of protein for over 5,000 years. The promotion of the tuna industry ties directly to culture. Food culture in the Pacific Islands states, "fishing and fish have formed a part of the mythology and technology of the island people for centuries." ${ }^{52}$ Fishing is a common practice is Pacific Island culture and increasing traditional and small vessel tuna fishing would provide an increase in tuna supply. All these traditional foods are all considered kakana dina, meaning real food in Fijian. ${ }^{53}$ Pacific Islanders understand there is a difference between the foods being imported and the foods they once cultivated. A survey in 2001 had islanders rank a list of foods. The results showed a preference towards traditional foods but a higher consumption of imported foods due to their price. ${ }^{54}$ This suggests that if traditional foods are available and at a comparable price to imported foods, the majority of the population would likely choose traditional foods. Using the methods above, all current interventions 2009), pg. 73

52. Roger Haden, Food Culture in the Pacific Islands (Santa Barbara, California: Greenwood Press, 53. Ibid., 57.

54. Curtis, Michael. "The Obesity Epidemic in the Pacific Islands." Journal of Development and Social Transformation. Accessed February 23, 2016. http://www.maxwell.syr.edu/uploadedFiles/moynihan/dst/curtis5.pdf 
will be built upon and incorporate culture, and new programs will be developed to enhance the response from the community and reclaim traditional foods.

Regarding traditional agriculture, it would be safest to promote small-scale subsistence farming. While agriculture is an important part of the PIC culture, the result of frequent natural disasters and increased rainfall in some regions makes large-scale agriculture operations risky. On a smaller scale, the loss would not be a great, and therefore food insecurity would be minimalized. Joketani Cokanisiga, Fiji's Agriculture Minister, encouraged the population to plant vegetable crops in personal gardens. ${ }^{55}$ If the Traditional Foods Program was able to provide seeds and demonstrate how to cultivate crops, this could be a reliable source of food for those living in poverty. Crops can be chosen based on the current environmental situation, and utilizing crops common to the land will help offset the risk of crop yields. Plants such a coconut trees are stronger than ground vegetables, and can hold up better in intense weather conditions. Fiji has experienced increased rainfall; therefore cultivating taro, a crop that thrives in wet and swampy lands would be a viable option. As well, taro is capable of growing in sandy soils, therefore atoll islands would cultivate taro as well. The increased cultivation could also help drive down the price of taro. ${ }^{56}$ These are all examples of ways countries can adapt their agriculture to their environment and needs. It will be important to increase the amount of fruits and vegetables imported to the Pacific Islands, and it could be beneficial to increase trading between islands if one island specializes in a particular crop. While a significant emphasis should be put on agriculture, imports should still be a source of food

55. Roger Haden, Food Culture in the Pacific Islands (Santa Barbara, California: Greenwood Press, 2009), pg.198.

56. Ibid., 59. 
security to bolster nutritional values especially during natural disasters that will negatively impact agriculture production.

Another area that will be particularly important for the PIC Traditional Foods Project is the integration of the elderly and youth population. Many young adults are choosing to move to urban areas; therefore traditional culture will need to be incorporated into urban living. For exampling, developing programs involving the cultivation of traditional gardens in urban areas, which is a trend occurring in many American cities. As the PICs modernize, there are aspects of the traditional lifestyle that will no longer be practical today; therefore blending traditional and modern ways will be necessary. It is important to note that the urban culture, as it was described up, still in many ways is reflective of Pacific Island culture. Learning traits such as cooking can be carried out in urban or rural areas. Encouraging the youth to take part in the program is important because they are the future of the PICs and for traditions to continue the younger generations must carry them on. Young adults in the PICs identify more with a global culture due to technology and media rather than the culture of the Pacific Islands. ${ }^{57}$ Immersing them in a rural and traditional setting could be beneficial in some cases. Because youth unemployment is high in urban areas, if agricultural jobs were available, this could encourage the young populations to move back to a rural and traditional setting. Instilling traditional values is important for the health of the community, but it is also important for the Pacific Islands to keep their culture alive.

Finally, it will be challenging to align cultural and health views. In the Pacific Island it is considered a sign of wealth when someone consumes a large amount of food.

57. Roger Haden, Food Culture in the Pacific Islands (Santa Barbara, California: Greenwood Press, 2009), 198. 
Also, imported foods from westernized countries are considered superior to some traditional foods. These are two traditional views that unfortunately do not align with a healthy diet. If imported foods shift from processed, high calorie foods to fruits and vegetables then it would beneficial if these imports were considered superior because it would help increase whole food consumption. On the other hand, the cultural connection between over consuming food and wealth is a norm that does not facilitate a healthy lifestyle. While many people are food insecure, it is not likely many people are over indulging daily, but it is a cultural view that must be discouraged through raising health awareness and teaching the implications of over consumptions. As the Native American model suggests, using posters and community conversation is an important way to raise awareness and curiosity in the community.

\section{$\underline{\text { Conclusion }}$}

Alterations of current programs and new interventions in dietary health are all focused on providing resources and assistance to the community. By providing access to land, cultural knowledge, and the necessary resources for the community to formulate a plan of action, based on their own assessments, each island will be equipped to develop a Traditional Foods Program. Additionally, outside assistance can be provided for the planning and implementation process.

This is a plan that highlights a new perspective on improving health, utilizing traditional culture of the PICs as the core of the intervention. There is evidence from both a Native American model and an Aborigines Intervention that consuming a traditional diet will improve health, and renew traditional culture among the community. This plan 
does not evaluate the costs and funding sources for the program. Therefore, for the program to be implemented each island would need to find funding and assess the amount of funding needed. Each country has different concerns regarding agriculture, poverty, food security, urbanization, and a source of funding. The goal of this thesis is to encourage the Pacific Islands to consider a cultural intervention to improve health, while also reviving traditional culture. There is strong connection between food and culture, and using this connection can make an impact on the diet and health of the community. The epidemic of NCDs in the Pacific Islands has created financial burdens, and has strained the health of many people. The health of the community directly marks the direction of the Pacific Islands' future. In Stuffed and Starved Raj Patel wrote, "We are encouraged to understand obesity to be, at the end of the day, an individual failing, an inability to deal with the farrago of choices offered to us, a deficit of impulse control. Conventional wisdom sees obesity as a symptom of an impoverished faculty of choice, never a result of an impoverished range of choices." ${ }^{15}$ Using culture, the Pacific Islands can collectively change the options that are available to them. This intervention has the ability to impact the health dynamic, further quality of life, and promote the future of the Pacific Islands. 


\section{Bibliography}

Ahmed, M., Maclean, J., Gerpacio, R., Sombilla, M. "Food Security and Climate Change in the Pacific Islands." Asian Development Bank. Accessed January 15, 2016.

http://www.adb.org/sites/default/files/publication/29078/climate-change-food-security.pdf

Almerico, Gina M. "Food and Identity: Food Studies, cultural, and personal identity." Journal of International Business and Cultural Studies. no. 8 (2014) http://www.aabri.com/manuscripts/141797.pdf

Anderson, Ian. "The Economic Costs of Non-Communicable Diseases in the Pacific Islands." The World Bank. (2012) http://www.worldbank.org/content/dam/Worldbank/document/the-economic-costs-ofnoncommunicable-diseases-in-the-pacific-islands.pdf

Bell, Johann D., "Diversifying the use of tuna to improve food security and public health in Pacific Island countries and territories," Marine Policy 51 (2015): 584 -591

http://www.sciencedirect.com.echo.louisville.edu/science/article/pii/S0308597X1400267X

Bell, Winnie F. "Organic Agriculture and Fair Trade in Pacific Island Countries." Food and Agriculture Organization of the United Nations. (2009) http://www.fao.org/3/a-ak356e.pdf

Cassels, Susan. "Overweight in the Pacific: links between foreign dependence, global food trade, and obesity in Federated States of Micronesia." Globalization and Health 10 no. 2 (2006).

http://globalizationandhealth.biomedcentral.com/articles/10.1186/1744-8603-2-10

Christoforou, A., Snowdon, W., Laesango, N., Vantucawaqa, S., Lamar, D., Alam, L., Lippwe, K., Havea, I., Tairea, K., Hoejskov, P., Waqanivalu, T., Webster, J. "Progress on Salt Reduction in the Pacific Islands: From Strategies to Action." Heart, Lung and Circulation 24 (2015): 503-509. http://www.sciencedirect.com.echo.louisville.edu/science/article/pii/S1443950614008087

Clarke, D., McKenzie, T. "Legislative Intervention to Prevent and Decrease Obesity in Pacific Island Countries," Allen \& Clark, Policy and Regulatory Specialists Limited, June, 182007. http://www.wpro.who.int/nutrition/documents/docs/Finalobesityreport.pdf?ua=1

Curtis, Michael. "The Obesity Epidemic in the Pacific Islands." Journal of Development and Social Transformation. Accessed February 23, 2016. http://www.maxwell.syr.edu/uploadedFiles/moynihan/dst/curtis5.pdf

Falconer D.G, Buckley A., and Colagirui, R. "Counting the cost of type 2 diabetes in Vanutau." Diabetes Research Clinical Practice. 87, no. 1 (2010): 92-7. http://www.ncbi.nlm.nih.gov/pubmed/19875191

Gali Brashers-Krug, "Understanding Oral Diabetes Medications," Voice of the Diabetic, last modified October 2007. https://nfb.org/images/nfb/publications/vod/vod_22_4/vodfal0712.htm

Goulding, W., Moss, P., McAlpine, C.A."Cascading effects of cyclones on the biodiversity of Southwest Pacific islands." Elsevier: Biological Conservation 193 (2016): 143-152.

http://www.sciencedirect.com.echo.louisville.edu/science/article/pii/S0006320715301701

Ichiho, H., Yurow, J., Aiaoto, N. "An Assessment of Non-Communicable Diseases, Diabetes, and Related Risk Factors in the Federated States of Micronesia, State of Yap: A Systems Perspective." Hawai'i Journal of Medicine \& Public Health 72, no. 5 (2013): 57-67.

http://www.ncbi.nlm.nih.gov/pmc/articles/PMC3689458/ 
McDonald, Andrea. "What the Pacific \& Mexico can tell us about soft drink taxes and public health." University of Otago. Accessed February 20, 2016. https://blogs.otago.ac.nz/pubhealthexpert/2015/08/18/what-the-pacific-mexico-can-tell-us-about-soft-drinktaxes-and-public-health/

Ofotalau, Alison. "Beating Unemployment in the Solomon Islands." The World Bank. Jan. 29, 2013. http://blogs.worldbank.org/eastasiapacific/beating-unemployment-in-the-solomon-islands

-- "Poverty and Employment in Asia and the Pacific." Asian Development Bank. October 27, 2015. Accessed February 20, 2016. http://www.adb.org/news/infographics/poverty-and-employment-asia-andpacific

Raj Patel, Stuffed and Starved: The Hidden Battle for the World Food System (Brooklyn, NY: Melville House Publishing, 2007), 273.

Roger Haden, Food Culture in the Pacific Islands (Santa Barbara, California: Greenwood Press, 2009)

Rogers, Joanne Z. and Still, Christopher D. "Obesity and Type 2 Diabetes." Obesity Action Coalition. Accessed February 20, 2016. http://www.obesityaction.org/wp-content/uploads/Diabetes.pdf

Satterfield, D., DeBruyn, L., Santos, M., Alonso, L., Frank, M. "Health Promotion and Diabetes Prevention in American Indian and Alaskan Native Communities - Traditional Foods Project 2008-2014." Center for Disease Control and Prevention. 65, no. 1 (2016): 4-10.

http://www.cdc.gov/mmwr/volumes/65/su/su6501a3.htm

Senthilingam, Meera. "How paraside became the fattest place in the world." Cable News Network, 2015. http://www.cnn.com/2015/05/01/health/pacific-islands-obesity

Skinner, M., Brewer, T., Lewis, R. "Ciguatera Fish Poisoning in the Pacific Islands." PLoS Neglected Tropical Diseases 5 no. 12 (2011): 1-18. http://www.ncbi.nlm.nih.gov/pmc/articles/PMC3236724/

Shrivastava, S., Shrivastava, P., Ramasamy, J. "Roles of self-care in management of diabetes mellitus." Journal of Diabetes and Metabolic Disorder 12, no. 14 (2013).

http://www.ncbi.nlm.nih.gov/pmc/articles/PMC3599009/

Stice, E., Shaw, H., Marti, C. "A Meta-Analytic Review of Obesity Prevention Programs for Children and Adolescents: The Skinny on Interventions that Work." Psychological Bulletin. 132, no. 5 (2006): 667-691. http://www.ncbi.nlm.nih.gov/pmc/articles/PMC1876697/

--"The State of Pacific Towns and Cities." Asian Development Bank (2012). http://www10.iadb.org/intal/intalcdi/PE/2012/07773.pdf

Thow, A., Swinburn, B., Colagiuri, S., Mere, D., Quested, C., Vivili, P., Leeder, S. "Trade and food policy: Case studies from three Pacific Island countries." Food Policy. 35 (2010): 556-564.

http://www.sciencedirect.com.echo.louisville.edu/science/article/pii/S0306919210000771

Tin, S., Kenilorea, G., Gadabu, E., Tasserei, J., Colagiuri, R. "The prevalence of diabetes complications and associated risk factors in Pacific Islands countries." Elsevier: Diabetes Research and Clinical Practice 103 (2014): 114-118.

http://www.sciencedirect.com.echo.louisville.edu/science/article/pii/S016882271300363X

Tin, S., Lee, C., Colagiuri, R. "A profile of diabetes in Pacific Island Countries and Territories." Elsevier: Diabetes Research and Clinical Practice 107 (2015): 233-246. 
http://www.sciencedirect.com.echo.louisville.edu/science/article/pii/S0168822714004707

Trahant, Mark. "Reversing Diabetes Rates in Indian Country." Indian Country Today Media Network. May 19, 2016. http://indiancountrytodaymedianetwork.com/2015/05/19/reversing-diabetes-rates-indian-country160402

Tuiketei, T., Snowdon, W., Waqa, G., Kremer, P., Schultz, J., and Vanualailai, N. "Pacific Obesity Prevention in Communities Project Fiji Country Report." Fiji School of Medicine and Deakin University. August 2010.

http://www.fsm.ac.fj/files/Country\%20OPIC\%20Fiji\%20report\%20with\%20cover\%20FINAL.pdf

--"Vanuatu." The World Bank, 2014. http://data.worldbank.org/country/vanuatu

Watson, K., and Treanor, S. "How mutton flaps are killing Tonga." BBC News. January 18, 2016. http://www.bbc.com/news/magazine-35346493

Wilson, Catherine. "Diabetes Epidemic Threatens Development Gains in Pacific Islands." Inter Press Service. Feb. 11, 2015. http://www.ipsnews.net/2015/02/diabetes-epidemic-threatens-development-gainsin-pacific-islands/ 